\title{
Sustainability and corrosion
}

Chris Atkins BEng Hons, PhD, FICE, CEng, FICorr

Technical Principal, Materials and Corrosion Technology, Mott MacDonald, Altrincham, UK (Orcid:0000-0003-1322-3759) (corresponding author: Chris.atkins@mottmac.com)
Paul Lambert BSc, PhD, CEng, CSci, FIMMM, FICorr

Visiting Professor, Centre for Infrastructure Management, Sheffield Hallam University, Sheffield, UK (Orcid:0000-0002-2815-1674)

As a part of the drive to reduce carbon dioxide emissions, embodied energy figures are under consideration for construction materials. One aspect that needs to be included is the loss of embodied energy associated with corrosion and degradation throughout the life of a structure. This paper presents a review of corrosion and protection methods from the point of view of whole-life embodied carbon. This paper presents the examples that provide the lowest embodied carbon option for different environments for steel and reinforced concrete.

Keywords: climate change/corrosion/sustainability

\section{Notation}

$b$ metal-environment-specific time exponent

D mass loss per unit area or penetration depth

$r_{\text {corr }} \quad$ corrosion rate experienced in the first year

$t \quad$ exposure time in years

\section{Introduction}

In assessing the sustainability of materials, embodied energy is often used. For the purposes of this work, embodied energy is defined here as the total primary energy consumed from direct and indirect processes associated with a product or service and within the boundaries of cradle to gate. This includes all activities from material extraction (quarrying/mining), manufacturing, transportation and right through to fabrication processes until the product is ready to leave the final factory gate (Circular Ecology, 2019). Figures can also be quoted in energy per kilogram of material that represents the embodied energy. To convert from energy to carbon dioxide, an understanding of how much carbon dioxide is generated for each megajoule of energy is required, and this varies depending on the production methods used. If the material is being reused, then the embodied energy is that of removing it from one place and fitting it in another. Hence reuse is favourable, provided that extensive travel and storage are not required. If a material involves a significant amount of recycled product, this may bring the embodied energy down, as a certain amount of the energy involved is already accounted for in converting raw materials into the recycled product. However, if the recycling process involves a significant transport of material and then energy usage to convert it into a useable product, then it may not. As an example, the extraction of raw materials for the manufacture of glass is relatively low energy, whereas recycling glass can involve extensive sorting and transport processes followed by grinding and remelting of the recycled material, which is relatively energy intensive (Khatib, 2009).

Once a structure has been built, corrosion may occur, leading to a reduction in capacity. This is also a waste of embodied carbon dioxide ('embodied carbon') that has been invested in producing the structure. The paper presents a review of the embodied energy expressed as carbon dioxide equivalent $\left(\mathrm{CO}_{2} \mathrm{e}\right)$ in current corrosion prevention practices.
Unless noted otherwise, the embodied energy figures are taken from the Inventory of Carbon and Energy Database V3.0 Nov 2019 (Circular Ecology, 2019). This database provides conversion factors to obtain a mass of embodied carbon for a given mass of material.

Cradle to gate does not consider the maintenance required over the operation life. If the material produced is thermodynamically unstable, it will have a tendency to be converted over time.

\section{Steel}

Steel is thermodynamically unstable. Iron ore is stable; it has energy applied to it to convert it to steel. If steel is not provided with a protection system, it will corrode in the presence of moisture. When it corrodes, this embodied energy is lost to the environment and wasted. The amount of wasted energy depends on how much metal is lost, which in turn depends on the corrosion rate.

\subsection{Atmospheric corrosion}

BS EN ISO 9223 (BSI, 2012a) publishes corrosivity categories with corresponding rates for steel. These describe the metal lost due to corrosion, either as a mass or as a depth of penetration; however, these are first-year corrosion rates only. BS EN ISO 9224 (BSI, $2012 b$ ) provides formulae that represent a typical reduction in time. For the first 20 years, the depth of attack is described thus:

1. $D=r_{\text {corr }} t^{b}$

where $D=$ either a mass loss per unit area or penetration depth, $r_{\text {corr }}=$ the corrosion rate experienced in the first year, $t=$ exposure time in years and $b=$ metal-environment-specific time exponent ( 0.523 for carbon steel, 0.813 for zinc).

For exposures greater than 20 years ISO 9224 (BSI, 2012b) proposes the following equation that assumes that the corrosion rate becomes linear at 20 years of exposure:

2. $D(t>20)=r_{\text {corr }}\left[20^{b}+b\left(20^{b-1}\right)(t-20)\right]$ 
where $D=$ either a mass loss per unit area or penetration depth, $r_{\text {corr }}=$ the corrosion rate experienced in the first year, $t=$ exposure time in years and $b=$ metal-environment-specific time exponent.

The mass of $\mathrm{CO}_{2} \mathrm{e}$ wasted is directly related to the mass of material lost due to corrosion. For steel, a figure of $1.55 \mathrm{kgCO}_{2} \mathrm{e}$ (kilograms of $\mathrm{CO}_{2} \mathrm{e}$ contained within a material)/kg has been used from the Inventory of Carbon and Energy Database V3.0 Nov 2019.

The standard method of protecting steel is the application of a coating system. Again, there are figures for the embodied energy of coatings. A generic coating contains $2.91 \mathrm{kgCO}_{2} \mathrm{e} / \mathrm{kg}$. Using a density similar to a typical two-pack epoxy of $1.62 \mathrm{~kg} / \mathrm{l}$ from a commercially available product in common usage, a litre of epoxy has $4.71 \mathrm{kgCO}_{2} \mathrm{e}$. One litre will cover $1 \mathrm{~m}^{2}$ of steel with a thickness of $1 \mathrm{~mm}$; so $1 \mu \mathrm{m}$ of wet coating has $0.0047 \mathrm{kgCO}_{2} \mathrm{e}$. This can then be further converted into a $\mathrm{CO}_{2} \mathrm{e}$ per micron of dry film thickness. This conversion depends on the volume solids of the specific coating used. Solvented coatings generally have a greater differential between wet and dry film thicknesses. In the analysis that follows, it is assumed that the coating remains intact until the coating life expires. This is obviously not the case, as coatings get damaged and break down with time. This is considered a necessary simplification to allow this evaluation. It is also assumed that the metal corrodes evenly at the maximum rate given in ISO 9223 (BSI, 2012a) for that environment. Localised corrosion due to crevices or pitting is not included. The embodied carbon considers just the material in reapplication, and nothing is associated with the temporary works, such as grit blasting, access and power requirements on site. So it is an underestimate, but the energy and carbon associated with these items would be distributed across the total area to be coated.

Table B2 of BS EN ISO 12944 (BSI, 2019) Part 5 provides an example of the minimum dry film thickness for a range of coating types to provide high durability (15-25 year life). It ranges from $160 \mu \mathrm{m}$, for $\mathrm{C} 2$ environments coated with alkyds, to $300 \mu \mathrm{m}$, for C5 coated with epoxies. The embodied energy figures are not for specific formulations but are based on typical values from the Inventory of Carbon and Energy Database V3.0. Table 1 presents the embodied carbon wasted when $1 \mathrm{~m}^{2}$ of steel corrodes for 15 years and the embodied carbon wasted by applying a coating to prevent this degradation.
It can be clearly seen that painting steel has a lower embodied energy than that which is wasted due to corrosion during a 15year period. It is a significant benefit to the environment in any corrosivity category more aggressive than $\mathrm{C} 1$. The $\mathrm{CO}_{2} \mathrm{e}$ wasted in steel corrosion over 15 years in a $\mathrm{C} 1$ environment is equivalent to a coating thickness of approximately $11 \mu \mathrm{m}$. It would be likely that a coating would not result in saving $\mathrm{CO}_{2} \mathrm{e}$. Epoxies generally involve less embodied carbon than alkyds based on the mass of coating used. Note that the $\mathrm{CO}_{2} \mathrm{e}$ figures are not specific for specific formulations. The $\mathrm{CO}_{2} \mathrm{e}$ saved by coating with an epoxy rather than letting the steel corrode ranges between approximately 0.58 and $8.30 \mathrm{~kg}$.

There are also figures for the embodied carbon of zinc $\left(3.09 \mathrm{kgCO}_{2} \mathrm{e} / \mathrm{kg}\right.$ ), so the same process can be repeated for both galvanised steel and coated galvanised steel. The thickness of hotdip galvanising depends on the element being galvanised, and so two figures are included, 45 and $85 \mu \mathrm{m}$. From Equation 1, zinc corrodes 9.02 times the first-year corrosion rate over 15 years. The embodied carbon figures are presented in Table 2, including the figures associated with the embodied $\mathrm{CO}_{2} \mathrm{e}$ of coatings. Note that the recommended coating thicknesses are not the same as that of steel that is not galvanised.

As can be seen, for all environments below $\mathrm{C} 5$ corrosivity, the $\mathrm{CO}_{2} \mathrm{e}$ wasted due to coating degradation is more than the $\mathrm{CO}_{2} \mathrm{e}$ wasted due to corrosion of the galvanising, regardless of the thickness of galvanising.

Table 2. Embodied carbon in coated galvanised steel

\begin{tabular}{|c|c|c|c|c|c|c|}
\hline & $\begin{array}{c}\text { Zinc } \\
\text { corrosion } \\
\text { rate: } \mu \mathrm{m} / \\
\text { year }\end{array}$ & $\begin{array}{l}\text { Mass } \\
\text { lost: } \\
\text { (kg/ } \\
\text { year)/ } \\
\text { m }^{2}\end{array}$ & $\begin{array}{l}\text { Mass } \\
\text { lost in } \\
15 \\
\text { years: } \\
\mathrm{kg} / \mathrm{m}^{2}\end{array}$ & $\begin{array}{c}\mathrm{kgCO}_{2} \mathrm{e} / \\
\mathrm{m}^{2} \\
\text { wastage } \\
\text { for } \\
45 \mu \mathrm{m}\end{array}$ & $\begin{array}{c}\mathrm{kgCO}_{2} \mathrm{e} / \\
\mathrm{m}^{2} \\
\text { wastage } \\
\text { for } \\
85 \mu \mathrm{m}\end{array}$ & $\begin{array}{c}\mathrm{CO}_{2} \mathrm{e} \text { in } \\
\text { coating: } \\
\mathrm{kgCO}_{2} \mathrm{e} / \\
\mathrm{m}^{2}\end{array}$ \\
\hline C1 & 0 & 0.001 & 0.006 & 0.020 & 0.020 & - \\
\hline$C 2$ & 0.7 & 0.005 & 0.045 & 0.140 & 0.140 & 0.444 \\
\hline$C 3$ & 2.1 & 0.015 & 0.136 & 0.421 & 0.421 & 0.666 \\
\hline C4 & 4.2 & 0.030 & 0.273 & 0.843 & 0.843 & 0.887 \\
\hline C5 & 8.4 & 0.060 & 0.546 & $8.175^{*}$ & 1.686 & 1.109 \\
\hline
\end{tabular}

*Denotes that galvanising has been fully depleted and steel corrosion has commenced

$\mathrm{kgCO}_{2} \mathrm{e}$, kilograms of $\mathrm{CO}_{2} \mathrm{e}$ contained within a material; - , not applicable

Table 1. Embodied carbon in coated steel

\begin{tabular}{|c|c|c|c|c|c|c|}
\hline $\begin{array}{l}\text { Corrosivity } \\
\text { category }\end{array}$ & $\begin{array}{l}\text { Steel corrosion } \\
\text { rate: } \mu \mathrm{m} / \mathrm{year}\end{array}$ & $\begin{array}{c}\text { Mass lost: } \\
(\mathrm{kg} / \text { year }) / \mathrm{m}^{2}\end{array}$ & $\begin{array}{l}\text { Mass lost in } 15 \\
\text { years: } \mathrm{kg} / \mathrm{m}^{2}\end{array}$ & $\begin{array}{l}\text { Energy wastage: } \\
\qquad \mathrm{kgCO}_{2} \mathrm{e} / \mathrm{m}^{2}\end{array}$ & $\begin{array}{l}\text { Energy in coating: } \\
\mathrm{kgCO}_{2} \mathrm{e} / \mathrm{m}^{2} \text { (epoxy) }\end{array}$ & $\begin{array}{l}\text { Energy in coating: } \\
\mathrm{kgCO}_{2} \mathrm{e} / \mathrm{m}^{2} \text { (alkyd) }\end{array}$ \\
\hline $\mathrm{C} 1$ & 1.30 & 0.01014 & 0.042 & 0.06 & Not required & Not required \\
\hline$C 2$ & 25 & 0.195 & 0.803 & 1.25 & 0.666 & 0.887 \\
\hline$C 3$ & 50 & 0.390 & 1.607 & 2.49 & 0.998 & 1.109 \\
\hline C4 & 80 & 0.624 & 2.571 & 3.98 & 1.331 & 1.442 \\
\hline C5 & 200 & 1.560 & 6.427 & 9.96 & 1.664 & Not recommended \\
\hline
\end{tabular}

$\mathrm{kgCO}_{2} \mathrm{e}$, kilograms of $\mathrm{CO}_{2} \mathrm{e}$ contained within a material 
For a $\mathrm{C} 2$ environment, $45 \mu \mathrm{m}$ of galvanising would provide 133 years before consumption. For a $\mathrm{C} 3$ environment, $45 \mu \mathrm{m}$ of zinc provides 41 years before steel corrodes. To achieve 100 years, either a corrosion allowance is required for 59 years' worth of corrosion or coatings are needed. This would be $483 \mu \mathrm{m}$ of steel corrosion $\left(5.84 \mathrm{kgCO}_{2} \mathrm{e}\right)$. If a coating with a 15 -year durability is applied once, this extends the life of the galvanising by at least 15 years, so the corrosion of steel is reduced by 15 years. The effects of repeated coating are presented in Figure 1. With no coating, the embodied carbon being wasted is initially that which is associated with the corrosion of zinc, in accordance with Equation 1. Once the zinc is depleted, the energy wasted is that which is associated with the corrosion of steel in accordance with Equation 1. For coated options, the coating life is assumed to be 15 years, after which the structure is either recoated or corrosion commences. Each coating exercise adds the embodied energy associated with the coating used. This is repeated to achieve a 100-year assumed design life.

In this case, the most carbon dioxide efficient approach is to coat the structure four times, with an embodied carbon of $3.60 \mathrm{kgCO}_{2} \mathrm{e} / \mathrm{m}^{2}$. The residual life is then made up of the corrosion of the galvanising.

As an alternative, $85 \mu \mathrm{m}$ could be applied. This would give 82 years before steel corrosion and so would only need to be recoated once to provide the most carbon dioxide efficient approach at $2.9 \mathrm{~kg}$, as illustrated in Figure 2.

In a $\mathrm{C} 3$ environment, the use of coated galvanised steel, with the thickest galvanising possible, produces the lowest embodied carbon.

A similar approach can be taken for a C4 environment. Forty-five microns of galvanising with no coating produces the responses shown in Figure 3.

The lowest $\mathrm{CO}_{2} \mathrm{e}$ option is also chosen to repeatedly coat the structure until the galvanising provides the corrosion resistance

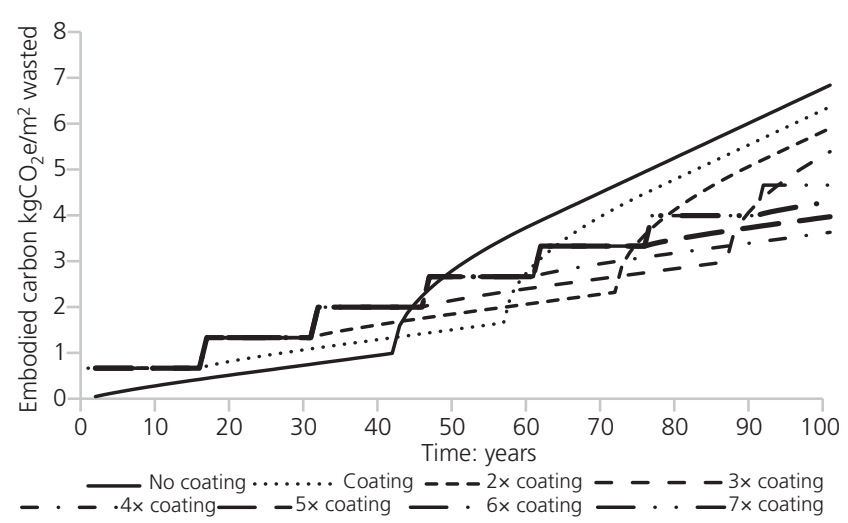

Figure 1. Carbon wasted due to corrosion in a C3 environment with $45 \mu \mathrm{m}$ galvanising

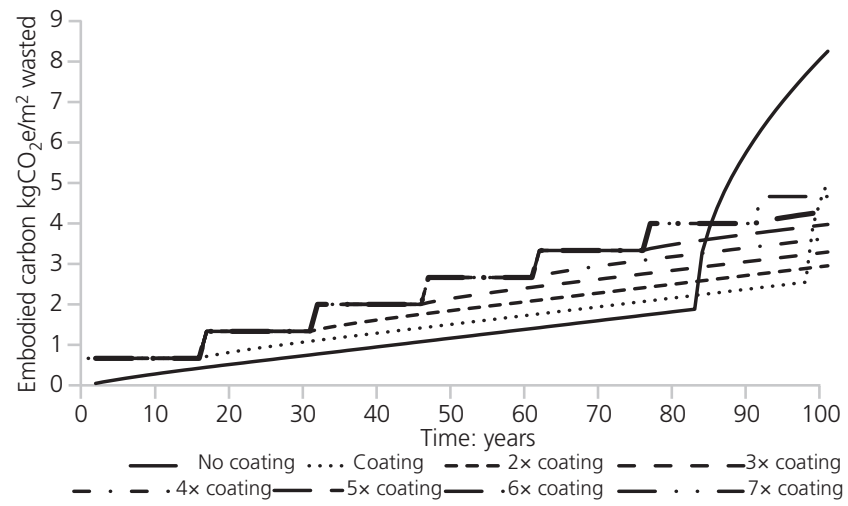

Figure 2. Carbon wasted due to corrosion in a C3 environment with $85 \mu \mathrm{m}$ galvanising

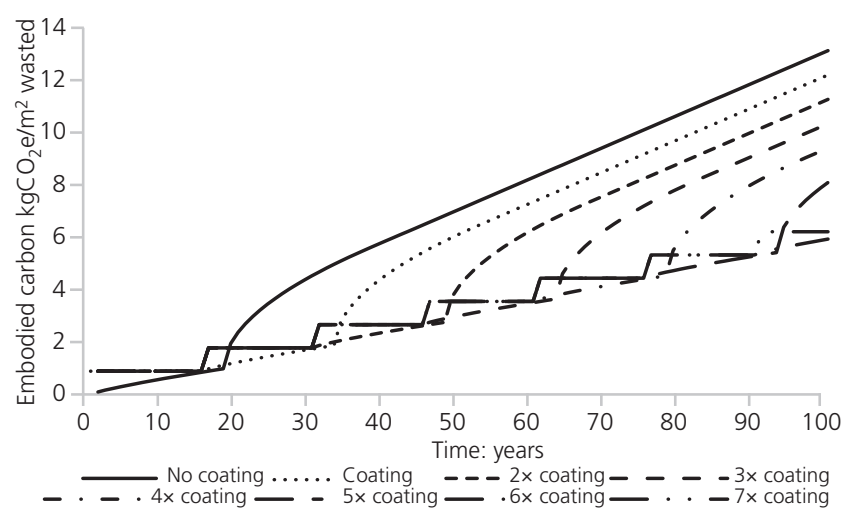

Figure 3. Carbon wasted due to corrosion in a C4 environment with $45 \mu \mathrm{m}$ galvanising

required for the structure's lifespan. In this case, with $45 \mu \mathrm{m}$ galvanising, recoating needs to take place six times.

For $85 \mu \mathrm{m}$ galvanising, shown in Figure 4, minimising embodied carbon required six recoats, although there is only a marginal gain (approximately $11 \mathrm{~g}$ ) between the fifth and sixth coating.

Based on Figure 4, the largest waste of $\mathrm{CO}_{2} \mathrm{e}$ occurs when the structural steel is allowed to corrode.

For a C5 environment, the results shown in Figure 5 are obtained. In effect, the approach needed is to keep recoating the steel, in which case the presence of galvanising does not minimise the embodied carbon and, therefore, could be omitted. In practical terms, the coating will not all fail at once and galvanising will improve the coating resistance to undercutting at defects. This would be of benefit, although additional thickness may not necessarily be a significant benefit.

One obvious approach would be to use a corrosion-resistant steel. Generic stainless steel typically has an embodied $\mathrm{CO}_{2} \mathrm{e}$ three times that of structural steel but will obviously not lose this $\mathrm{CO}_{2} \mathrm{e}$ 


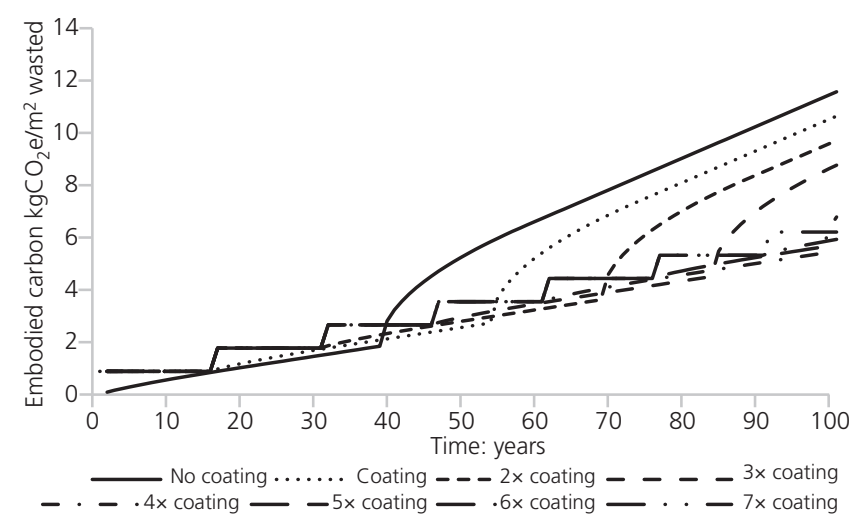

Figure 4. Carbon wasted due to corrosion in a C4 environment with $85 \mu \mathrm{m}$ galvanising

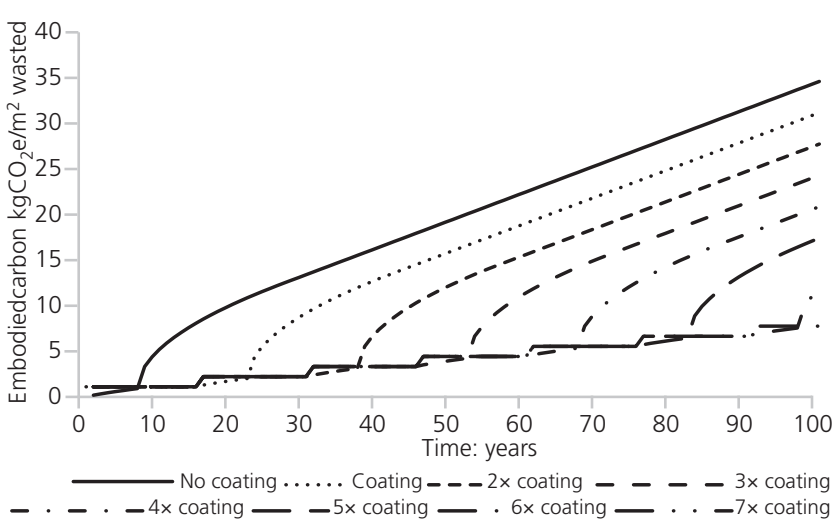

Figure 5. Carbon wasted due to corrosion in a C5 environment with $45 \mu \mathrm{m}$ galvanising

by corroding. It is worth noting that most grades of stainless steel will corrode in the presence of chlorides, and many are not resistant to crevice corrosion. Based on these figures and those calculated for $\mathrm{CO}_{2} \mathrm{e}$ wasted in the $\mathrm{C} 3$ or $\mathrm{C} 4$ environment above, the use of structural stainless steel uses more embodied $\mathrm{CO}_{2} \mathrm{e}$ than coated structural steel where the member thicknesses are over $0.13 \mathrm{~mm}$ in a $\mathrm{C} 3$ environment or $0.26 \mathrm{~mm}$ in a $\mathrm{C} 4$ environment.

\subsection{Buried or submerged steel}

For buried or submerged steel, inspection and recoating are more complex than atmospherically exposed steel as the structure cannot be easily accessed. The approach to managing corrosion is either to use corrosion allowances, coatings, cathodic protection or a combination of these. Corrosion allowances can often be employed because the stresses involved in manufacture and installation exceed those required in service, and so the material is naturally thicker than required. Coatings prevent the steel from being exposed to the environment but they degrade with time and are vulnerable to damage. Cathodic protection applies a voltage that relocates the corrosion processes so that the steel does not corrode. Combined coatings and cathodic protection reduces the size of the cathodic protection system required, and allows for coating damage to be tolerated.

BS EN 1993-5 (BSI, 2007) provides corrosion rates or amounts of section loss for buried steel. These are reproduced in Table 3 for a range of different lifespans. The section loss can be converted to $\mathrm{CO}_{2} \mathrm{e}$ wasted, and the figures are shown in Table 4 .

While it would not be possible to reapply a coating, in many cases, it could be applied prior to installation. Table C6 in BS EN 12944 (BSI, 2019) Part 5 has a maximum application thickness of $600 \mu \mathrm{m}$ to provide very high durability ( $>25$ years). Assuming a similar

Table 3. BS EN 1993 corrosion allowances (buried steel)

\begin{tabular}{lccccc} 
& \multicolumn{5}{c}{ Duration of exposure } \\
\cline { 2 - 6 } Environment & $\begin{array}{c}5 \\
\text { years: } \\
\mathrm{mm}\end{array}$ & $\begin{array}{c}25 \\
\text { years: } \\
\mathrm{mm}\end{array}$ & $\begin{array}{c}50 \\
\text { years: } \\
\mathrm{mm}\end{array}$ & $\begin{array}{c}\text { years: } \\
\mathrm{mm}\end{array}$ & $\begin{array}{c}\text { years: } \\
\mathrm{mm}\end{array}$ \\
\hline $\begin{array}{c}\text { Undisturbed soils } \\
\begin{array}{c}\text { Polluted natural soils } \\
\text { and industrial sites }\end{array}\end{array}$ & 0.06 & 0.30 & 0.60 & 0.90 & 1.20 \\
$\begin{array}{c}\text { Aggressive natural } \\
\text { soils }\end{array}$ & 0.20 & 1.00 & 1.75 & 2.50 & 3.25 \\
$\begin{array}{c}\text { Non-compacted and } \\
\text { non-aggressive fills }\end{array}$ & 0.18 & 0.07 & 1.20 & 1.70 & 2.20 \\
$\begin{array}{c}\text { Non-compacted and } \\
\text { aggressive fills }\end{array}$ & 0.50 & 2.00 & 3.25 & 4.50 & 5.75 \\
\hline
\end{tabular}

Table 4. $\mathrm{CO}_{2} \mathrm{e}$ values of corrosion allowances in BS EN 1993-5 (BSI, 2007)

\begin{tabular}{|c|c|c|c|c|c|}
\hline \multirow[b]{2}{*}{ Environment } & \multicolumn{5}{|c|}{ Duration of exposure } \\
\hline & $\begin{array}{c}\mathrm{kgCO}_{2} \mathrm{e} / \\
\mathrm{m}^{2} \\
\text { after } 5 \\
\text { years }\end{array}$ & $\begin{array}{c}\mathrm{kgCO}_{2} \mathrm{e} \\
/ \mathrm{m}^{2} \\
\text { after } 25 \\
\text { years }\end{array}$ & $\begin{array}{c}\mathrm{kgCO}_{2} \mathrm{e} / \\
\mathrm{m}^{2} \\
\text { after } 50 \\
\text { years }\end{array}$ & $\begin{array}{c}\mathrm{kgCO}_{2} \mathrm{e} / \\
\mathrm{m}^{2} \\
\text { after } 75 \\
\text { years }\end{array}$ & $\begin{array}{c}\mathrm{kgCO}_{2} \mathrm{e} / \\
\mathrm{m}^{2} \\
\text { after } \\
100 \\
\text { years }\end{array}$ \\
\hline $\begin{array}{l}\text { Undisturbed } \\
\text { soils }\end{array}$ & 0.7 & 3.6 & 7.3 & 11 & 15 \\
\hline $\begin{array}{l}\text { Polluted } \\
\text { natural soils } \\
\text { and } \\
\text { industrial } \\
\text { sites }\end{array}$ & 1.8 & 9.1 & 18 & 27 & 36 \\
\hline $\begin{array}{l}\text { Aggressive } \\
\text { natural soils }\end{array}$ & 2.4 & 12 & 21 & 30 & 39 \\
\hline $\begin{array}{l}\text { Non- } \\
\text { compacted } \\
\text { and non- } \\
\text { aggressive } \\
\text { fills }\end{array}$ & 2.2 & 8.5 & 15 & 21 & 27 \\
\hline $\begin{array}{l}\text { Non- } \\
\text { compacted } \\
\text { and } \\
\text { aggressive } \\
\text { fills }\end{array}$ & 6.0 & 24 & 39 & 54 & 70 \\
\hline
\end{tabular}

$\mathrm{kgCO}_{2} \mathrm{e}$, kilograms of $\mathrm{CO}_{2} \mathrm{e}$ contained within a material 
embodied $\mathrm{CO}_{2} \mathrm{e}$ to the epoxy coating used above this would equate to $3.3 \mathrm{kgCO}_{2} \mathrm{e} / \mathrm{m}^{2}$. This is lower than the $\mathrm{CO}_{2} \mathrm{e}$ wasted for any of the environments over any increment of 25 years. Note that for a 100year lifespan, the coating means that the steel is only exposed for 75 years, so the coating should be compared with the difference between a 75 - and 100-year exposure.

\subsection{Corrosion rates in freshwater/marine environments} BS EN 1993-5 (BSI, 2007) also provides corrosion rates or amounts of section loss for immersed steel. These are reproduced in Table 5 for a range of different environments and lifespans.

These can be converted to $\mathrm{CO}_{2} \mathrm{e}$ wasted, and the figures are shown in Table 6 .

As with buried steel, this could be coated prior to installation, with an associated embodied carbon of $3.30 \mathrm{kgCO}_{2} \mathrm{e}$. This is lower than

Table 5. Recommended value for the loss of thickness $(\mathrm{mm})$ due to corrosion for piles and sheet piles in freshwater or in seawater

\begin{tabular}{|cccccc}
$\begin{array}{l}\text { Required design working } \\
\text { life }\end{array}$ & $\begin{array}{c}\mathbf{5} \\
\text { years }\end{array}$ & $\begin{array}{c}\mathbf{2 5} \\
\text { years }\end{array}$ & $\begin{array}{c}\mathbf{5 0} \\
\text { years }\end{array}$ & $\begin{array}{c}\mathbf{7 5} \\
\text { years }\end{array}$ & $\begin{array}{c}\mathbf{1 0 0} \\
\text { years }\end{array}$ \\
$\begin{array}{c}\text { Common freshwater (river, } \\
\text { ship canal, ...) in the zone } \\
\text { of high attack (water line) }\end{array}$ & 0.15 & 0.55 & 0.90 & 1.15 & 1.40 \\
$\begin{array}{c}\text { Very polluted freshwater } \\
\text { (sewage, industrial } \\
\text { effluent, ...) in the zone of } \\
\text { high attack (water line) }\end{array}$ & 0.30 & 1.30 & 2.30 & 3.30 & 4.30 \\
$\begin{array}{c}\text { Seawater in temperate } \\
\text { climate in the zone of high } \\
\text { attack (low-water and } \\
\text { splash zones) }\end{array}$ & 0.55 & 1.90 & 3.75 & 5.60 & 7.50 \\
$\begin{array}{c}\text { Seawater in temperate } \\
\text { climate in the zone of } \\
\text { permanent immersion or in } \\
\text { the intertidal zone }\end{array}$ & 0.25 & 0.90 & 1.75 & 2.60 & 3.50 \\
\hline
\end{tabular}

Table 6. $\mathrm{CO}_{2} \mathrm{e}$ values of corrosion allowances in BS EN 1993-5 (immersed)

\begin{tabular}{lccccc}
$\begin{array}{l}\text { Required design working } \\
\text { life }\end{array}$ & $\begin{array}{c}\mathbf{5} \\
\text { years }\end{array}$ & $\begin{array}{c}\mathbf{2 5} \\
\text { years }\end{array}$ & $\begin{array}{c}\mathbf{5 0} \\
\text { years }\end{array}$ & $\begin{array}{c}\mathbf{7 5} \\
\text { years }\end{array}$ & $\begin{array}{c}\mathbf{1 0 0} \\
\text { years }\end{array}$ \\
$\begin{array}{l}\text { Common freshwater (river, } \\
\text { ship canal, ..) in the zone } \\
\text { of high attack (water line) }\end{array}$ & 1.8 & 6.6 & 11 & 14 & 17 \\
$\begin{array}{l}\text { Very polluted freshwater } \\
\text { (sewage, industrial effluent, }\end{array}$ & 3.6 & 16 & 28 & 40 & 52 \\
$\begin{array}{l}\text {..) in the zone of high } \\
\text { attack (water line) }\end{array}$ & & & & & \\
$\begin{array}{l}\text { Seawater in temperate } \\
\text { climate in the zone of high } \\
\text { attack (low-water and } \\
\text { splash zones) }\end{array}$ & 6.6 & 23 & 45 & 68 & 91 \\
$\begin{array}{l}\text { Seawater in temperate } \\
\text { climate in the zone of } \\
\text { permanent immersion or in } \\
\text { the intertidal zone }\end{array}$ & 3.0 & 11 & 21 & 31 & 42 \\
\hline
\end{tabular}

the $\mathrm{CO}_{2} \mathrm{e}$ wasted for any of the environments over any increment of 25 years in most cases. The only exception is the long lifespans in common freshwater. Again, for a 100-year lifespan, the coating means that the steel is only exposed for 75 years, so the coating should be compared with the difference between a 75 - and 100 -year exposure.

\subsection{Cathodic protection of steel}

When steel is buried or immersed, it is possible to employ cathodic protection $(\mathrm{CP})$. There are two distinct approaches, either using a metal that will corrode in place of the steel (galvanic CP), or an external power supply (impressed current CP). BS EN ISO 15589-1 (BSI, 2017) reports the typical current densities for the protection of bare steel or cast iron fall within the range $0.1-1 \mathrm{~A} / \mathrm{m}^{2}$. In a galvanic system, the mass of anode lost corresponds to the amount of current required for protection. The capacity of anode materials is quoted in BS EN 12496 (BSI, 2010 ) in terms of ampere hours per kilogram of anode. Zinc has a capacity of approximately $780 \mathrm{~A} \mathrm{~h} / \mathrm{kg}$, aluminium has a capacity of $2500 \mathrm{~A} \mathrm{~h} / \mathrm{kg}$. The embodied carbon corresponds to the mass lost, with zinc and aluminium having embodied energy figures of 3.09 and $6.67 \mathrm{kgCO}_{2} \mathrm{e} / \mathrm{kg}$, respectively. Table 7 illustrates the embodied carbon wasted to protect $1 \mathrm{~m}^{2}$ of uncoated steel for 25 years at a current density of $0.1 \mathrm{~A} / \mathrm{m}^{2}$, requiring a total of 2.5 A years. Note that a full CP design is more complex than these simple examples may indicate.

The most $\mathrm{CO}_{2} \mathrm{e}$ the steel wastes is $24 \mathrm{~kg}$. It is quite clear that the use of galvanic $\mathrm{CP}$ employs materials with higher embodied carbon to prevent corrosion of a material having lower embodied carbon. From a sustainability point of view, it is significantly more efficient to use a thicker section and allow the steel to corrode.

Impressed current CP will typically employ anodes that do not corrode and an external power supply. The energy required for protection is applied voltage $\times$ current $\times$ time. The required voltage depends on the resistance of the overall circuit, which is a function of the anode dimensions and resistivity of the soil, plus the cabling. There is an additional $\mathrm{CO}_{2} \mathrm{e}$ requirement embodied in the power supply and cabling. The anode does incur a $\mathrm{CO}_{2} \mathrm{e}$, but this is not wasted as the anode is not significantly consumed. A bigger anode will give a lower anode resistance and hence a lower drive voltage, but will obviously require more anode material. Assuming a drive voltage of $8 \mathrm{~V}$, to provide the same amount of current, the energy used is $175 \mathrm{~kW} / \mathrm{h}$ over 25 years. The current government conversion to $\mathrm{CO}_{2} \mathrm{e}$ in the UK is $0.2556 \mathrm{kgCO}_{2} \mathrm{e} /(\mathrm{kW} \mathrm{h})$ (BEIS, 2019), while $17 \mathrm{~kW} / \mathrm{h}$ is equivalent to $44 \mathrm{kgCO}_{2} \mathrm{e}$.

Table 7. $\mathrm{CO}_{2}$ e values for anode mass required for 25-year life at $0.1 \mathrm{~A} / \mathrm{m}^{2}$

$\begin{array}{lc}\text { Anode material } & \text { Embodied } \mathbf{k g C O} \text { e for } \mathbf{2 . 5} \text { A years: } \mathbf{k g} \\ \text { Aluminium } & 58 \\ \text { Zinc } & 91\end{array}$

$\mathrm{kgCO}_{2} \mathrm{e}$, kilograms of $\mathrm{CO}_{2} \mathrm{e}$ contained within a material 
The energy value appears to be a significant saving, but the current needs to be outputted by an anode, which is typically titanium, and the system will need power supplies and external control systems. Titanium has an embodied $\mathrm{CO}_{2} \mathrm{e}$ of between 20 and $42 \mathrm{~kg} \mathrm{CO} \mathrm{CO}_{2} \mathrm{e} / \mathrm{kg}$. An anode rated at $2.5 \mathrm{~A}$ for use in soil weighs $180 \mathrm{~g}$, and so the anode has an embodied carbon of 3.6-7.5 $\mathrm{kgCO}_{2} \mathrm{e}$. Note that this could protect $25 \mathrm{~m}^{2}$, so the $\mathrm{CO}_{2} \mathrm{e}$ per square metre is $0.15-0.30 \mathrm{kgCO}_{2} \mathrm{e}$. There would be additional carbon dioxide associated with cabinets and cables, but the figure likely to be most significant is any computer control system. Figures for embodied carbon of these items are not readily available. If the system is computer controlled, there are published figures for embodied energy of items such as memory chips. A 2 GB memory card in 2009 was reported to contain $2700 \mathrm{MJ}$ of embodied energy (De Decker, 2009). Direct conversion depends on a number of assumptions, but using UK electricity equivalent figures, this would be approximately $190 \mathrm{kgCO}_{2} \mathrm{e}$. This is a significant mass, but a computer-based system would be used to protect a large area of steel, so again, its effect would be reduced if assessed on a per-square-metre-of-steel basis and is likely to be less than $1 \mathrm{kgCO}_{2} \mathrm{e} / \mathrm{m}^{2}$. While a computer-controlled system may sound attractive, consideration should be given as to whether the additional functionality is actually of benefit, given the cost of embodied carbon associated with it.

\section{Concrete}

Ordinary Portland cement (OPC) is universally recognised as a significant contributor to carbon dioxide emissions on a cradle-to-gate basis, and so concrete is often considered to be poor. In making reinforced concrete structures, it should not be forgotten that reinforced concrete contains steel and aggregate and that it is common to use cement replacements. These materials are typically industrial byproducts. Typically, in the UK, the most common materials were pulverised fuel ash (PFA), from coal-fired power stations, or ground granulated blast-furnace slags (GGBSs) from steel manufacturers, but as these industries have reduced production, the by-products needed are often now imported. Taking a $254 \mathrm{~mm} \times 254 \mathrm{~mm} \times 107 \mathrm{~kg} / \mathrm{m}$ steel universal column, it is considered similar to a $450 \times 450 \mathrm{~mm}$ reinforced concrete column. The embodied carbon in the steel column, at $1.55 \mathrm{kgCO}_{2} \mathrm{e} / \mathrm{kg}$ is $165 \mathrm{kgCO}_{2} \mathrm{e} / \mathrm{m}$. For the concrete equivalent, the mass of concrete per metre of column is approximately $485 \mathrm{~kg}$. The embodied energy of an OPC mix is $0.138 \mathrm{kgCO}_{2} \mathrm{e} / \mathrm{kg}$, giving $67 \mathrm{kgCO}_{2}$ e per metre of column. If $30 \%$ PFA is used, this is reduced to $46 \mathrm{kgCO}_{2} \mathrm{e}$ per metre of column, and for $70 \%$ GGBS, this is reduced further to $25 \mathrm{kgCO}_{2} \mathrm{e}$ per metre of column. Steel reinforcement is required. Assuming four No. $12 \mathrm{~mm}$ dia. bars, with $8 \mathrm{~mm}$ dia. links at $225 \mathrm{~mm}$ centres, this adds a further $10 \mathrm{kgCO}_{2} \mathrm{e}$ per linear metre, which is a significant contribution to the $\mathrm{CO}_{2} \mathrm{e}$. The total $\mathrm{kgCO}_{2} \mathrm{e}$ per metre of a concrete column is therefore approximately $77 \mathrm{kgCO}_{2} \mathrm{e} / \mathrm{m}$ for an OPC mix, which is reduced to $35 \mathrm{kgCO}_{2} \mathrm{e} / \mathrm{m}$ when the column is made using cement replacements. The uncoated steel equivalent contains significantly more $\mathrm{CO}_{2} \mathrm{e}$ than the reinforced concrete column.

When concrete is made, the material is generally thermodynamically stable. It may deteriorate in the presence of sulfates, acids or aggressive carbon dioxide, but in standard buried or atmospherically exposed environments, over the typical lifetime of a structure, it is inert. It also provides corrosion protection to the steel, and so, from gate to grave, it has no additional $\mathrm{CO}_{2} \mathrm{e}$.

The steel can start to corrode if the concrete either carbonates or gets contaminated with chlorides. Carbonation is a process that is sometimes used to suggest that concrete can be used as a storage of carbon dioxide. Atmospheric carbon dioxide is absorbed, but this results in a reduction of the $\mathrm{pH}$ of the concrete. Unfortunately, the reason that steel does not corrode in concrete is its high $\mathrm{pH}$, and so once carbonation depths reach the steel, it will start to corrode. The rate of carbonation is a function of the external environment and mix design. Dry concrete can carbonate quickly, but without moisture, the steel will not corrode. External UK concrete generally carbonates slowly due to the moisture levels in the environment. Carbonation-induced corrosion of external concrete structures in the UK is generally confined to those with extremely low-cover $(<20 \mathrm{~mm})$ or poor-quality concrete. Typically, wherever the steel is in a carbonated environment, in the presence of moisture, it will corrode. For chloride-induced corrosion to occur, a critical amount of chloride needs to penetrate the concrete to the depth of the steel. Unlike carbonation-induced corrosion, the corrosion sites do not occur everywhere within a chloride-contaminated zone. This means that if repairs are undertaken without due regard for the presence of chlorides, corrosion will initiate in unrepaired areas after the initial repair.

When steel corrodes in concrete, typically, the corrosion product is expansive and causes spalling at even a relatively small amount of section loss. Repairs involve identifying the cause (chlorides, carbonation or a combination of the two) and then either removing all the contaminated or carbonated concrete and reinstating or repairing the damage and addressing the contamination. In the case of carbonated concrete, corrosion will typically occur wherever the contamination is, so the removal and reinstatement of loose material do not leave significant possible future corrosion. It does, however, require the replacement of the original concrete with a repair material, and this needs to be compared with the embodied energy of a method that could prevent this degradation.

The typical prevention method for carbonated concrete would be the use of an anti-carbonation coating. Representative figures for the embodied carbon of anti-carbonation coatings are not available, but they are likely to be similar to the steel coatings discussed above. Five hundred microns of epoxy would equate to approximately $2.7 \mathrm{kgCO}_{2} \mathrm{e}$, and by preventing carbonation, it prevents the removal and reinstatement of a $100 \mathrm{~mm}$ thick layer of concrete, assuming that breaking out behind the bar is required. The repair concrete is likely to have more polymer than the original, so it is likely to be more carbon dioxide intensive. For this reason, it is practical to use the embodied $\mathrm{CO}_{2} \mathrm{e}$ for $\mathrm{OPC}$ concrete rather than anything where the carbon dioxide has been reduced. 
This volume of standard concrete has a value of $33 \mathrm{kgCO}_{2} \mathrm{e}$, and so, if there is a risk of carbonation, repeated applications of anticarbonation coatings with an embodied carbon of $2.7 \mathrm{kgCO}_{2} \mathrm{e}$ are likely to be the lowest embodied carbon option. One key difference between coating steel and coating concrete is that steel will start to corrode once the coating fails, whereas concrete will start to carbonate, and then in time, the reinforcement will start to corrode. It is therefore not necessary to instantly repair failed coatings on concrete to prevent corrosion.

It is not unusual for chloride contamination to be significant by the time repairs are undertaken, and so the removal of all the concrete is required. As an alternative, CP can be employed, and chloridecontaminated but structurally sound concrete can remain in place. This saves significant embodied carbon due to the reduced amount of material removal and reinstatement. It is commonly considered that for chloride-contaminated concrete, approximately $10 \%$ of the concrete will have been spalled by the time of repair, adding $3.3 \mathrm{kgCO}_{2} \mathrm{e}$ as a repair material. A common approach is to use a specially coated titanium mesh in a sprayed concrete overlay. If a mesh and overlay system is used, there will be an additional $300 \mathrm{~g}$ of titanium mesh $\left(10 \mathrm{kgCO}_{2} \mathrm{e}\right)$, and $25 \mathrm{~mm}$ of sprayed concrete overlay $\left(8 \mathrm{kgCO}_{2} \mathrm{e}\right)$, giving a total additional $\mathrm{CO}_{2} \mathrm{e}$ per square metre of $21.3 \mathrm{~kg}$, compared with $33 \mathrm{~kg}$ to replace $100 \mathrm{~mm}$ of concrete. As with anti-carbonation coatings, chloride ingress could be prevented with coatings with an embodied carbon value of $2.7 \mathrm{kgCO}_{2} \mathrm{e}$, which would significantly lower $\mathrm{CO}_{2} \mathrm{e}$ than would allowing corrosion to take place.

The installation of the titanium mesh could be included in the original construction and could be energised if required. This would require fewer anodes, probably of the order of $100 \mathrm{~g} / \mathrm{m}^{2}\left(3 \mathrm{kgCO}_{2} \mathrm{e}\right)$, and unlike a coating, these would not be needed to be reapplied, which means that the $\mathrm{CP}$ installed during construction is likely to be the lowest embodied carbon option, if there is a risk of chloride-induced corrosion. There would be an ongoing energy consumption associated with the operation of a system. This depends on the operating voltage and current being passed. One square metre of concrete typically requires $2 \mathrm{~mA} / \mathrm{m}^{2}$ to prevent corrosion, rising to $10 \mathrm{~mA} / \mathrm{m}^{2}$ to reverse active corrosion. The operating voltage would be expected to be between 2 and $8 \mathrm{~V}$, giving an annual energy requirement between $0.035 \mathrm{~kW} / \mathrm{h}$ and $0.7 \mathrm{~kW} / \mathrm{h}$, or $0.01-0.18 \mathrm{kgCO}_{2} \mathrm{e}$ per annum. Considering a 100-year life, installing CP to reinforced concrete during construction would add $4 \mathrm{kgCO}_{2} \mathrm{e} / \mathrm{m}^{2}$. Considerations with regard to computer-controlled systems are similar to those with the protection of buried or immersed steel.

\section{Conclusions}

Based on embodied $\mathrm{CO}_{2} \mathrm{e}$ calculations, the following can be stated.

Atmospherically exposed steel

- In a $\mathrm{C} 1$ environment, coatings do not reduce $\mathrm{CO}_{2} \mathrm{e}$ over the life of the structure.
- In a $\mathrm{C} 2$ environment, $45 \mu \mathrm{m}$ of galvanising results in the lowest lifetime waste of $\mathrm{CO}_{2} \mathrm{e}$.

- In a $\mathrm{C} 3$ environment, $85 \mu \mathrm{m}$ of galvanising and recoating once results in the lowest lifetime waste of $\mathrm{CO}_{2} \mathrm{e}$.

- In a $\mathrm{C} 4$ environment, $85 \mu \mathrm{m}$ of galvanising and recoating five times results in the lowest lifetime waste of $\mathrm{CO}_{2} \mathrm{e}$.

- In a $\mathrm{C} 5$ environment, $85 \mu \mathrm{m}$ of galvanising and repeatedly recoating every 15 years produces the lowest lifetime waste of $\mathrm{CO}_{2} \mathrm{e}$.

- Stainless steels generally use more $\mathrm{CO}_{2} \mathrm{e}$ than any of the above options.

Buried/submerged steel

- An initial coating prior to installation reduces the lifetime waste of $\mathrm{CO}_{2} \mathrm{e}$ in all cases apart from a long-term immersion in fresh water.

- $\mathrm{CP}$ uses more $\mathrm{CO}_{2} \mathrm{e}$ than a corrosion allowance.

- Impressed current $\mathrm{CP}$ systems have lower $\mathrm{CO}_{2}$ e than galvanic CP systems; computer control systems should not be overspecified.

Reinforced concrete

- In an example column, reinforced concrete has lower $\mathrm{CO}_{2} \mathrm{e}$ than an equivalent steel column before coating.

- If there is a risk of carbonation-induced corrosion, coating and recoating the concrete wastes less $\mathrm{CO}_{2} \mathrm{e}$ than allowing the corrosion to take place and then undertaking concrete repair.

- If chloride-induced corrosion has taken place, impressed current $\mathrm{CP}$ wastes less $\mathrm{CO}_{2} \mathrm{e}$ than concrete replacement.

- If there is a risk of chloride-induced corrosion, coating the concrete wastes less $\mathrm{CO}_{2} \mathrm{e}$ than allowing the corrosion to take place. The inclusion of an impressed current $\mathrm{CP}$ system at the time of construction wastes the smallest amount of $\mathrm{CO}_{2} \mathrm{e}$.

\section{REFERENCES}

BEIS (Department for Business, Energy \& Industrial Strategy) (2019) Greenhouse Gas Reporting: Conversion Factors 2019. BEIS, London, UK. See https://www.gov.uk/government/publications/greenhouse-gasreporting-conversion-factors-2019 (accessed 19/11/2021).

BSI (2007) BS EN 1993-5: Eurocode 3. Design of steel structures - Part 5: Piling. BSI, London, UK.

BSI (2010) BS EN 12496: Galvanic anodes for cathodic protection in seawater and saline mud. BSI, London, UK.

BSI (2012a) BS EN ISO 9223: Corrosion of metals and alloys. Corrosivity of atmospheres. Classification, determination and estimation. BSI, London, UK.

BSI (2012b) BS EN ISO 9224: Corrosion of metals and alloys. Corrosivity of atmospheres. Guiding values for the corrosivity categories. BSI, London, UK.

BSI (2017) BS EN ISO 15589-1: Petroleum, petrochemical and natural gas industries. Cathodic protection of pipeline systems. On-land pipelines. BSI, London, UK.

BSI (2019) BS EN ISO 12944-5: Paints and varnishes. Corrosion protection of steel structures by protective paint systems. Protective paint systems. BSI, London, UK. 
Circular Ecology (2019) Embodied Carbon - The ICE Database. Circular Ecology, Bristol, UK. See www.circularecology.com/embodiedcarbon-footprint-database.html (accessed 19/11/2021).

De Decker K (2019) The monster footprint of digital technology.

Low-Tech Magazine, 16 June. See https://www.lowtechmagazine.com/ 2009/06/embodied-energy-of-digital-technology.html (accessed 19/11/ 2021).

Khatib JM (ed.) (2009) Sustainability of Construction Materials. Woodhead Publishing, Cambridge, UK.

\section{How can you contribute?}

To discuss this paper, please email up to 500 words to the editor at journals@ice.org.uk. Your contribution will be forwarded to the author(s) for a reply and, if considered appropriate by the editorial board, it will be published as discussion in a future issue of the journal.

Proceedings journals rely entirely on contributions from the civil engineering profession (and allied disciplines). Information about how to submit your paper online is available at www.icevirtuallibrary.com/page/authors, where you will also find detailed author guidelines. 